\title{
Histological type of oncogenity and expression of cell cycle genes in tumor cells from human mesenchymal stem cells
}

\author{
RUNQIU JIANG ${ }^{1}$, WENRONG XU ${ }^{1}$, WEI ZHU ${ }^{1},{\text { MIAO } \text { CHEN }^{2} \text {, HUI QIAN }}^{1}$, CHUN QIAO $^{1}$, \\ HUAN YANG ${ }^{1}$, XINGZHONG WANG ${ }^{1}$ and YONGCHANG CHEN ${ }^{2}$ \\ ${ }^{1}$ School of Medical Technology, Zhenjiang Key Institute of Clinical Laboratory Medicine, ${ }^{2}$ School of Medicine, \\ Jiangsu University, 2 Dongwu Road, Zhenjiang, Jiangsu 212001, P.R. China
}

Received June 26, 2006; Accepted August 2, 2006

\begin{abstract}
In previous experiments, a novel tumor cell line, which was characterized by dominated F6 mutated from human mesenchymal stem cells (hMSCs), was developed. The mechanism and biological characteristics of this mutation are still unclear. In this study, the histological type of F6 cells was investigated by immunohistochemistry with specific markers: vimentin, CD117, desmin, NSE and vWF. The characteristics of proliferation and metastasis were shown by PCNA (proliferating cell nuclear antigen), and nm23 and cell cycle-related genes, such as p16, p21, p53 and pRb, were analyzed by RT-PCR and immunohistochemistry. The expression of hTRAP and BMI-1 were detected by real-time PCR and Western blotting. The activity of telomerase was analyzed by TRAP (telomerase repeat amplification protocol) assay. The results showed that multi-directional differentiation occurred in F6 cells, i.e., special markers of muscle, endothelial cell and nerve system were co-expressed in F6 cells, while hardly expressed in hMSCs. F6 cells maintained the same properties as of MSCs, such as negativity for both CD117 and vimentin. F6 cells exhibited strong positivity for PCNA and negativity for $\mathrm{nm} 23$. The cell cycle-related genes, such as p16, p21, p53 and pRb, were not detected in F6 cells, while the expression of hTRAP and BMI-1 was significantly higher. The activity of telomerase was also significantly higher in F6 cells than that in hMSCs. These findings indicated that multidirectional differentiation occurred during the transformation of hMSCs into F6 cells, and that the genes of cell cycle and cell senescence may also be associated with the neoplasia of adult stem cells.
\end{abstract}

Correspondence to: Dr Wenrong Xu, School of Medical Technology, Jiangsu University, 2 Dongwu Road, Zhenjiang, Jiangsu 212001, P.R. China

E-mail: icls@ujs.edu.cn

Key words: human mesenchymal stem cells, tumor, histological type, telomerase

\section{Introduction}

Stem cells can be defined as having extensive self-renewal capacity and the ability to differentiate into a wide variety of cell types. However, the tumorigenesis potential of hematopoietic stem cells has been well known for many years. For example, a number of hematological malignancies, especially chronic myeloid leukemia, present stem cell characteristics (1), but little data support the fact that other kinds of stem cells hold neoplastic potential. Recently, however, a number of groups have demonstrated that stem cells are present in adult tissues and become targets of carcinogenesis and transformation. In our previous experiments, a novel tumor cell line (F6) was established from mutated human fetal bone marrow stem cells which were induced by cytokines in vitro (2). In addition, Serakinci et al reported that adult human mesenchymal stem cells transduced with the telomerase hTERT gene at 256 of the population doubling level (PDL) showed loss of contact inhibition, anchorage independence and formed tumors in 10/10 mice (3). Recent studies on solid tumors showed that the capacity for self-renewal is limited to a subpopulation of tumor cells - cancer stem cells which can be separated from other tumor cells by specific markers of stem cells $(4,5)$. F6 is a line of tumor cells which is directly mutated from stem cells. Are there histological changes underlying its neoplasia? Although we reported that an important gene, nucleostemin, may be associated with the transformation of hMSCs to F6 cell (6), it is still unclear whether there is any different expression of cell cycle- or cell senescence-associated genes between these two kinds of cells. In this study, the histological type of F6 cells was analyzed by immunohistochemistry, and the activity of the immortalizing enzyme, telomerase, was detected by TRAP assay. The expression of some genes related to cell cycle or cell senescence was detected in both the levels of transcription and protein.

\section{Materials and methods}

Isolation of MSCs and cell culture. Human fetal MSCs were isolated from the bone marrow of a 40 -week-old fetus that died in a traffic accident. The bone marrow aspirated from the posterior iliac crests was collected into syringes containing heparin $(6000 \mathrm{U})$. Mononuclear cells were isolated by $1.073 \mathrm{~g} /$ 
$\mathrm{ml}$ of Ficoll, with centrifugation at $1100 \mathrm{x} \mathrm{g}$ for $30 \mathrm{~min}$, as described previously (7). The cells were rinsed twice with PBS and seeded with a density of $1-2 \times 10^{5} / \mathrm{cm}^{2}$ in complete DMEM medium (low glucose, Gibco) containing $10 \%$ fetal calf serum (FCS, Gibco), 5\% horse serum (HS, Gibco), penicillin $(100 \mathrm{U} / \mathrm{ml})$ and streptomycin $(100 \mu \mathrm{g} / \mathrm{ml})$. The cells were then incubated at $37^{\circ} \mathrm{C}$ in humid air containing $5 \% \mathrm{CO}_{2}$. Three days later, non-adherent cells (hematopoietic cells) were removed by replacing medium into other tubes. After ten days in culture, adherent cells formed colonies and became homogeneous. These cells were trypsinized $(0.25 \%$ trypsin with $0.1 \%$ EDTA, Sigma) and replated at a density of $8000 / \mathrm{cm}^{2}(\sim 1: 3)$ and the medium was changed every three days. The harvested cells were induced to form multiple lineages, such as bone, cartilage, neuron, adipocyte and cardiomyocyte under the defined culture conditions (8-10). The results of these experiments confirmed that MSCs were properly obtained and the MSCs at passage 4 were used for experiments.

Immunohistochemistry. Human MSCs were treated with BSA (bovine serum albumin) (Sino-American Biotechnology Co.), and the tumor tissue samples of F6 cells were fixed in 4\% formaldehyde solution embedded in paraffin, were sectioned (5- $\mu \mathrm{m}$ thick) and mounted on slides. The slices were rehydrated through a gradient of toluene and alcohol, and probed with antibodies against PCNA, nm23, p16, p53, vimentin, CD117, desmin, NSE and vWF respectively according to the manufacturer's instructions (Boster Bioengineering Co. Ltd., Wuhan, P.R. China), followed by incubation with secondary antibody at $37^{\circ} \mathrm{C}$ for $30 \mathrm{~min}$ and reacted with DAB reagent for 5-10 min. The slices were mounted with neutral gum for microscopic examination. The immunohistochemical results were evaluated semi-quantitatively by the staining intensity of tumor cells compared to the adjacent, non-stained cells. A brown-yellow color in the nucleus was evaluated as a nucleus-positive cell. The samples in which $<30 \%$ of the cells in the section were stained in the nucleus or cytoplasm were defined as nuclei-positive $(+)$ or cytoplasm positive $(+)$, while the samples with $>30 \%$ and $<60 \%$ stained cells were evaluated as nuclei-positive $(++)$ or cytoplasm positive $(++)$. The tissue sections with $>60 \%$ stained cells were considered as strong nuclei-positive $(+++)$ or cytoplasm positive $(+++)$.

Western blotting. MSCs and F6 cells were grown to $90 \%$ confluence, and the BMI-1 protein of cell nuclei and cytoplasm was extracted with buffer A (for cytoplasm) containing $10 \mathrm{mM}$ HEPES-KOH (pH 7.9), $10 \mathrm{mM} \mathrm{KCl}, 1.5 \mathrm{mM} \mathrm{MgCl}_{2}, 1 \mathrm{mM}$ DTT, $0.4 \mathrm{mM}$ PMSF and buffer B (for nuclei) containing $20 \mathrm{mM}$ HEPES-KOH (pH 7.9), $420 \mathrm{mM} \mathrm{NaCl}, 1.5 \mathrm{mM} \mathrm{MgCl}_{2}, 0.2 \mathrm{mM}$ EDTA, $0.1 \mathrm{mM}$ EGTA, 25\% glycerol, $1 \mathrm{mM}$ DTT, $0.4 \mathrm{mM}$ PMSF, $10 \mu \mathrm{g} / \mathrm{ml}$ leupeptin, $10 \mu \mathrm{g} / \mathrm{ml}$ aprotinin, $30 \mu \mathrm{g} / \mathrm{ml}$ SBTI, $3 \mu \mathrm{g} / \mathrm{ml}$ peptastatin A, $3 \mu \mathrm{g} / \mathrm{ml}$ bestatin, $20 \mathrm{mM}$ ß-glycerolphosphatase, $10 \mu \mathrm{M} \mathrm{NaVO}_{4}, 0.15 \mathrm{mM}$ spermine, $0.8 \mathrm{mM}$ spermidine. The extracted protein of nuclei was analyzed by Western blotting. The blotted nitrocellulose film was incubated with goat-anti BMI-1 IgG antibody (Zymed $^{\circledR}$ Laboratories Inc., catalog no. 37-5400) and then peroxidaseconjugated rabbit anti-goat secondary antibody (1:5000) was added. The results of the blotting were visualized via a chemiluminescent detection system (Western blotting luminol reagent, Santa Cruz Biotechnology) and exposed to autoradiography film (Kodak XAR film).

RNA isolation and reverse transcriptase polymerase chain reaction $(R T-P C R)$. To detect the difference in expression of BMI-1 and hTRAP between the F6 cells and MSCs, total RNA in the cells was isolated using TRIzol reagent (Invitrogen, USA) and cDNA was synthesized in $20 \mu 1$ of reaction volume

Table I. Primer sequence for the amplification of target genes and GAPDH.

\begin{tabular}{|c|c|c|c|}
\hline Genes & Primers $\left(5^{\prime}-3^{\prime}\right)$ & Amplicon size (bp) & Annealing temperature $\left({ }^{\circ} \mathrm{C}\right)$ \\
\hline BMI-1 & $\begin{array}{l}\text { Forward: AATCTAAGGAGGAGGTGA } \\
\text { Reverse: CAAACAAGAAGAGGTGGA }\end{array}$ & 359 & 59 \\
\hline p16 & $\begin{array}{l}\text { Forward: CGTGGTCTCCGTCATTGGT } \\
\text { Reverse: TACCTGTAAATGCCATCACCC }\end{array}$ & 255 & 56 \\
\hline p53 & $\begin{array}{l}\text { Forward: ACCCAGGTCCAGATGAAG } \\
\text { Reverse: CACTCGGATAAGATGCTGA }\end{array}$ & 459 & 58 \\
\hline $\mathrm{pRb}$ & $\begin{array}{l}\text { Forward: TGGAGTTCGCTTGTATTAC } \\
\text { Reverse: ATCAGTTGGTCCTTCTCG }\end{array}$ & 485 & 58 \\
\hline $\mathrm{p} 21$ & $\begin{array}{l}\text { Forward: TATGCCGTGGTCCAGAAGG } \\
\text { Reverse: GTGGGTGAGGTGAGGTGTC }\end{array}$ & 468 & 59 \\
\hline hTRAP & $\begin{array}{l}\text { Forward: CTGTGCTCTGCGGTCTCA } \\
\text { Reverse: TCGTCGTCCCATCTGTC }\end{array}$ & 414 & 58 \\
\hline GAPDH & $\begin{array}{l}\text { Forward: GGATTTGGTCGTATTGGG } \\
\text { Reverse: GGAAGATGGTGATGGGATT }\end{array}$ & 205 & 55 \\
\hline
\end{tabular}



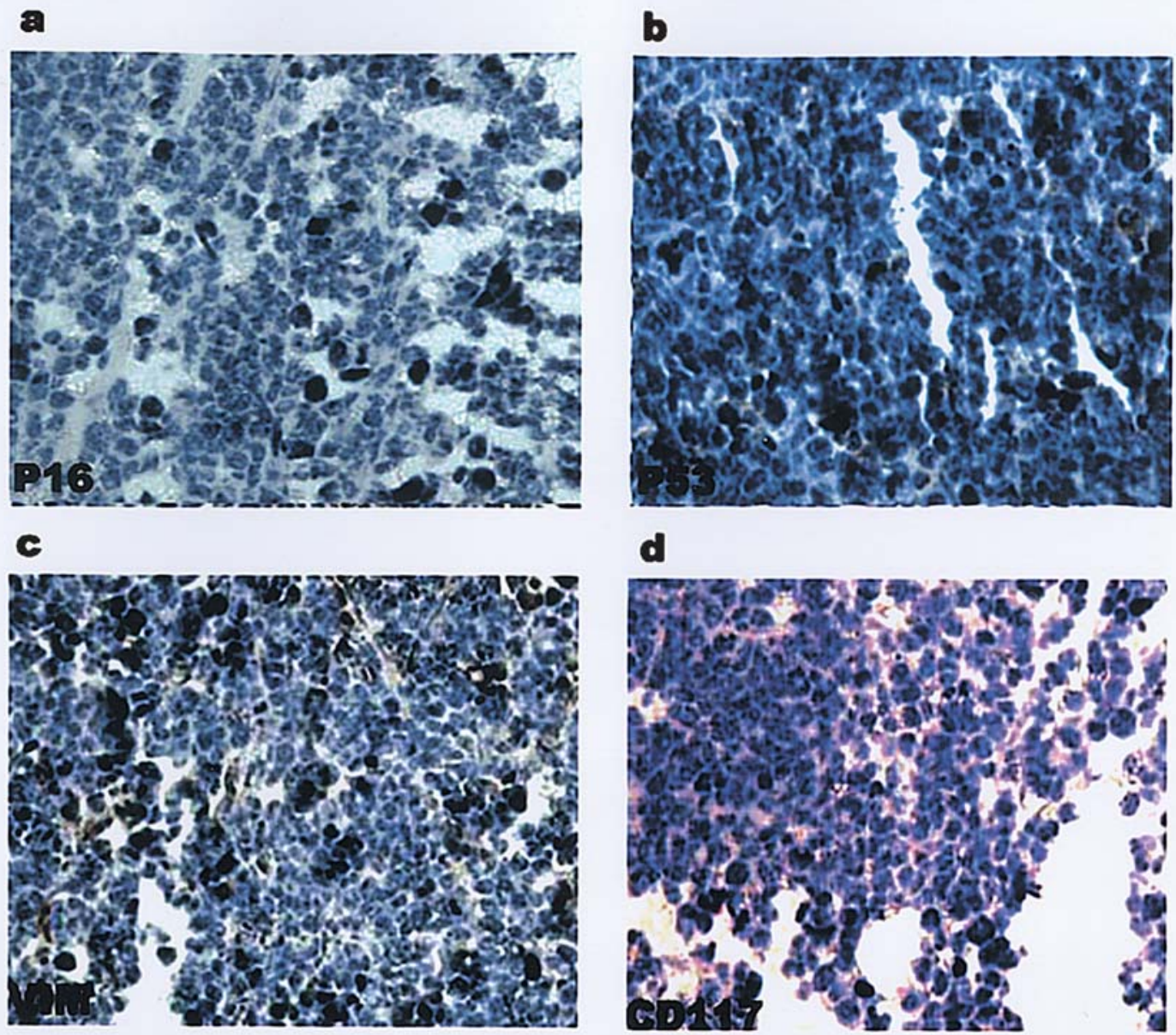

d

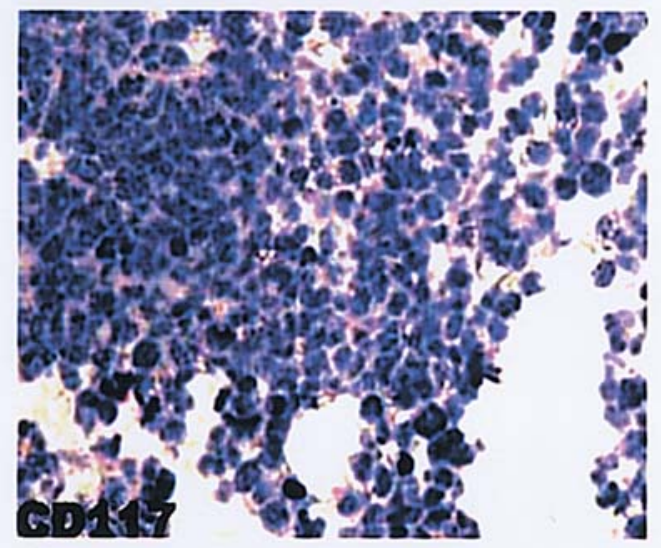

e

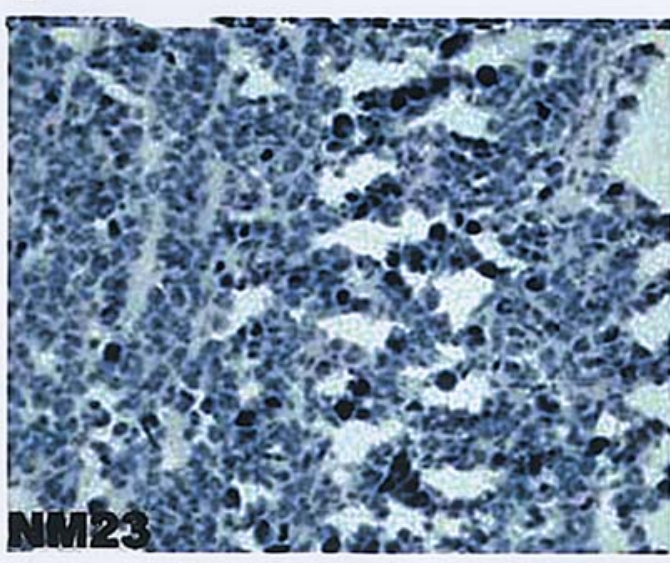

$f$

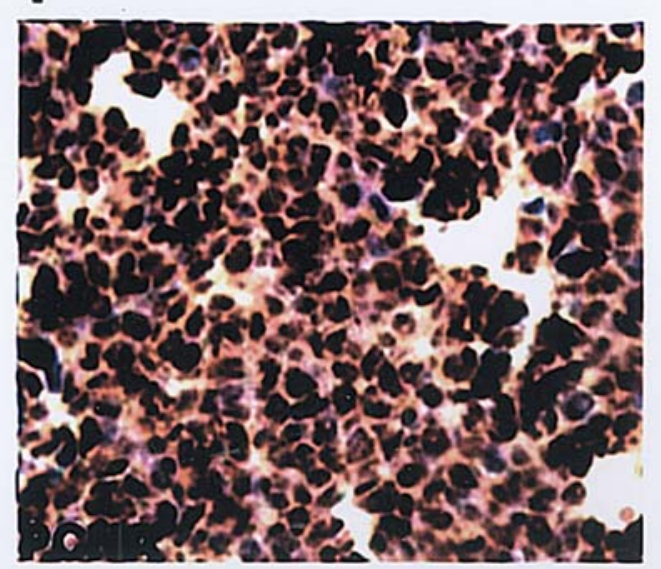

Figure 1. Immunohistochemistry staining of F6 cells. (a-e) Immunohistological analysis of F6 cells for p16, p53, Vimentin, CD117, nm23 and PCNA

containing $4 \mu \mathrm{g}$ of total RNA and SuperScript ${ }^{\mathrm{TM}}$ II RT according to the manufacturer's instructions (Invitrogen). In twenty-five microliters of reaction mixture, $0.5 \mu 1 \mathrm{cDNA}, 10 \mathrm{pmol}$ of each primer, $2 \mathrm{mM} \mathrm{MgCl}_{2}, 2.5 \mu 1200 \mathrm{nM} \mathrm{dNTP}$, and 1 unit of Taq DNA polymerase were included. The thermal cycle profile for PCR was $94^{\circ} \mathrm{C}$ for 5 min followed by 35 cycles of $30 \mathrm{sec}$ at $94^{\circ} \mathrm{C}, 30 \mathrm{sec}$ at annealing temperature $\left(56^{\circ} \mathrm{C}\right.$ for $\mathrm{p} 16,58^{\circ} \mathrm{C}$ for $\mathrm{pRb}$ and $\mathrm{p} 53$, and $59^{\circ} \mathrm{C}$ for $\left.\mathrm{p} 21\right), 30 \mathrm{sec}$ at $72^{\circ} \mathrm{C}$ with an additional $10 \mathrm{~min}$ of incubation at $72^{\circ} \mathrm{C}$ after completion of the last cycle. The specific primers of p16, p21, p53 and pRB were designed as shown in Table I.

The amplified fragments of the target genes were cloned into pGEM $^{\circledR}$ vector (Promega, USA) and DNA sequencing was performed by Gene Co. Ltd. (Shanghai, P.R. China). The standard curves were prepared by serial dilution of pGEMBMI-1, pGEM-hTRAP and pGEM-GAPDH vector. In twenty-five microliters of reaction mixture, $1 \mu 1$ of $1: 1500$ SYBR $^{\circledR}$-Green I, $0.5 \mu 1$ cDNA, 10 pmol of each primer, $2 \mathrm{mM}$ $\mathrm{MgCl}_{2}, 2.5 \mu 1200 \mathrm{nM} \mathrm{dNTP}$ and 1 unit of Taq DNA polymerase were included. To compensate for variations in input RNA amounts and efficiency of reverse transcription, an endogenous 'housekeeping' gene (glyceraldehydes-3phosphate dehydrogenase, GAPDH) was also quantified and used to normalize the results. The thermal cycle profile for PCR was $94^{\circ} \mathrm{C}$ for $2 \mathrm{~min}$ followed by 35 cycles of $30 \mathrm{sec}$ at $94^{\circ} \mathrm{C}, 30 \mathrm{sec}$ at annealing temperature $\left(59^{\circ} \mathrm{C}\right.$ for BMI- $1,58^{\circ} \mathrm{C}$ 


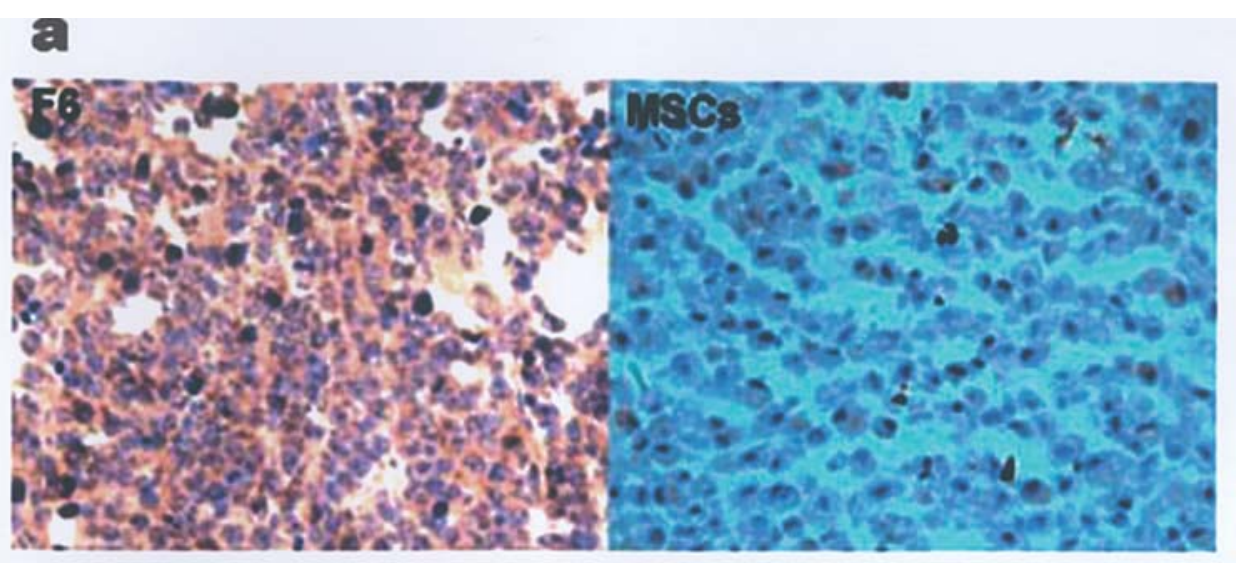

b

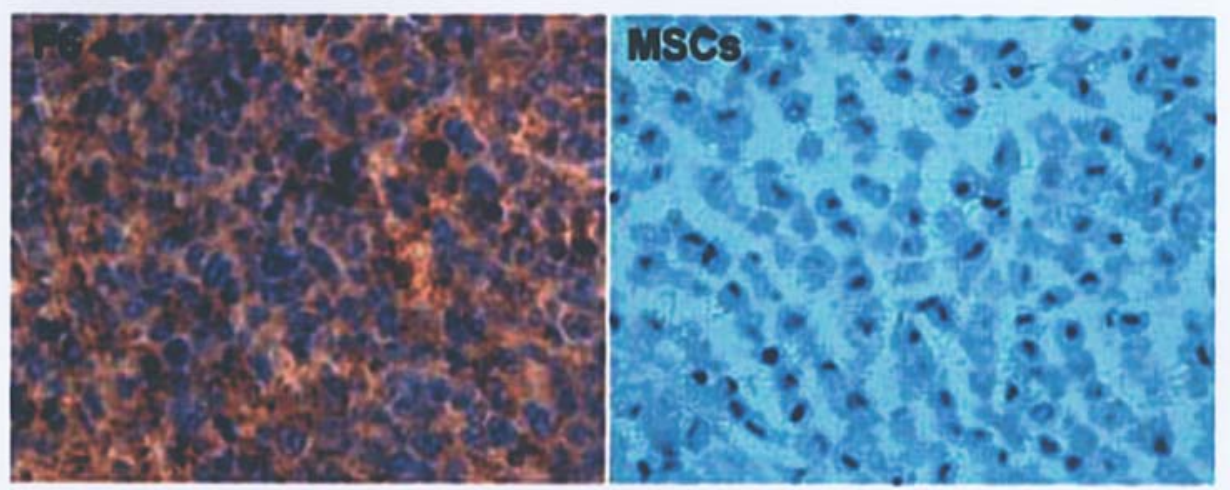

C

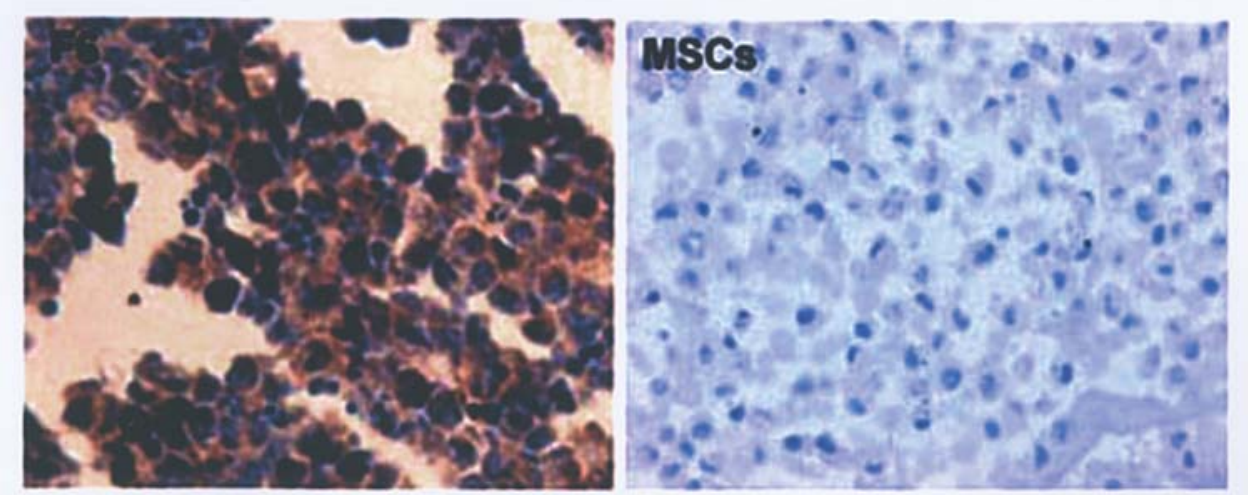

Figure 2. Multidifferentiation occurred during the mutation of hMSCs to F6 cells. (a) Immunohistological staining of FVIII for F6 cells and hMSCs, (b) immunohistological staining of Desmin for F6 cells and hMSCs and (c) immunohistological staining of NSE for F6 cells and hMSCs.

for hTRAP and $55^{\circ} \mathrm{C}$ for GAPDH) and $30 \mathrm{sec}$ at $72^{\circ} \mathrm{C}$. The PCR products were size-fractioned by $2 \%$ agarose gel electrophoresis. The BMI-1, hTRAP and GAPDH specific primers were designed as shown in Table I.

After the cycling of PCR assay was completed, the samples were subjected to a temperature ramp (from $45-95^{\circ} \mathrm{C}$ at $0.5^{\circ} \mathrm{C} / 2 \mathrm{sec}$ ) with continuous fluorescence monitoring for melting curve analysis. A triplicate was made of each sample and all reactions were repeated six times independently to ensure the reproducibility of the results. The data were then viewed and analyzed by Rotor-Gene real-time analysis software (Rotor-Gene 2000, CR, Australia). For each sample the amplification plot and the corresponding dissociation curves were examined. To obtain standardized quantitative results, external controls consisting of cDNA plasmid standards were constructed.

Telomerase activity. Telomerase activity in cell extracts was measured by PCR-based telomere repeat amplification protocol (TRAP) using a TRAPeze ${ }^{\circledR}$ telomerase detection kit (Chemicon, S7700, USA). Briefly, the cells were washed in phosphate-buffered saline and homogenized in the CHAPS lysing buffer for $30 \mathrm{~min}$ on ice. Then the protein $(50 \pm 100 \mathrm{ng})$ from each cell extract and a heat-inactivated sample as negative control were analyzed in the TRAP reaction. The cell extracts were directly added to the TRAP reaction 

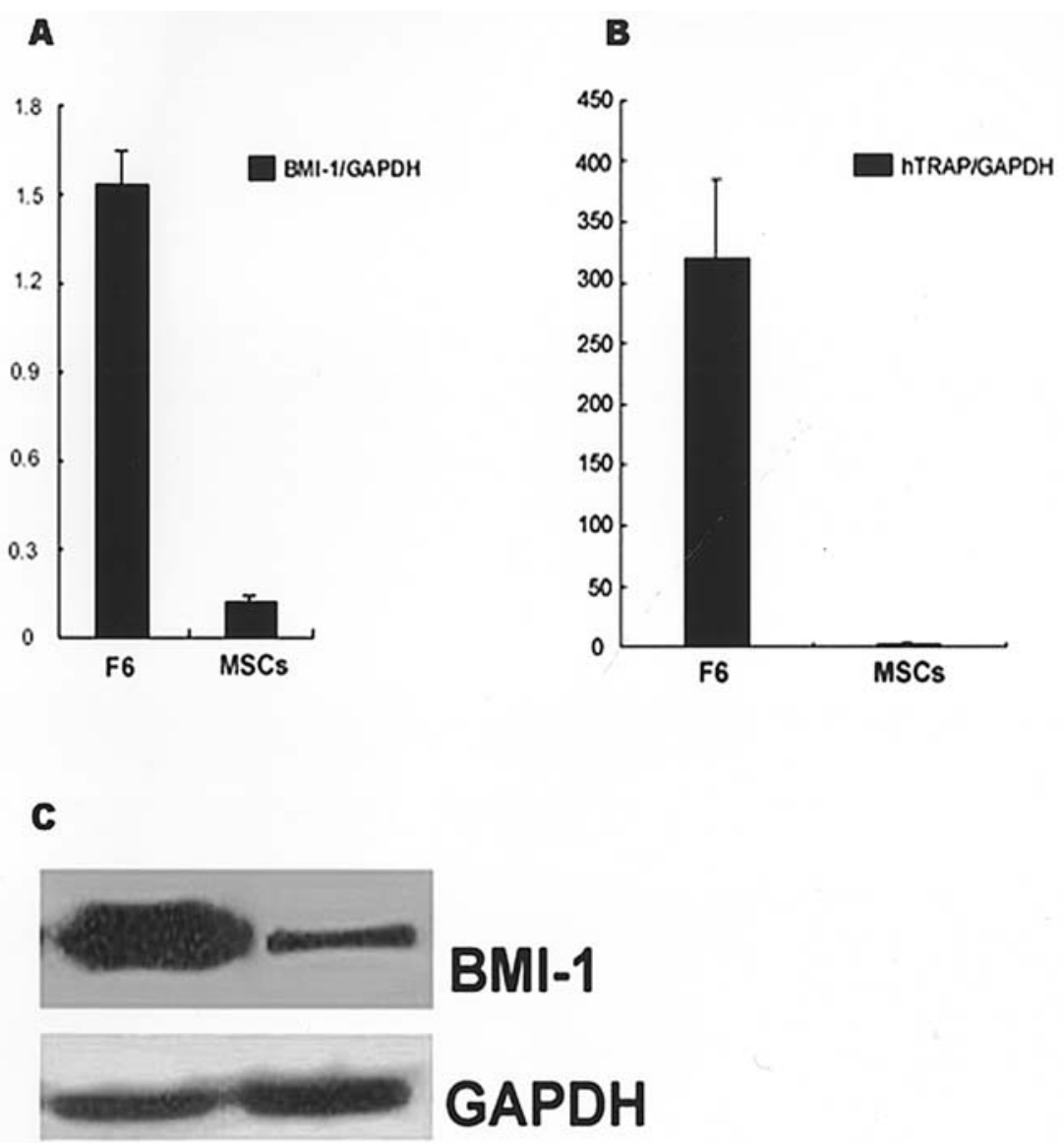

Figure 3. The mRNA expression of the BMI1 and hTRAP genes in F6 cells and hMSCs. (A) The expression of the BMI-1 gene in F6 cells and hMSCs, (B) the expression of the hTRAP gene in F6 cells and hMSCs and (C) the expression of BMI-1 in F6 cells and MSCs analyzed by Western blotting. The mRNA expression of different BMI1 and hTRAP is related to GAPDH expression.

mixture containing dNTPs, TS primer, reverse primer mixture and Taq DNA polymerase. The extended telomerase products were amplified by two-step PCR $\left(94^{\circ} \mathrm{C}, 30 \mathrm{sec}\right.$ and $\left.59^{\circ} \mathrm{C}, 30 \mathrm{sec}\right)$ for 27 cycles. Then the products were run in $12.5 \%$ acrylamide gel with $0.5 \mathrm{X}$ TBE buffer and stained by $1: 10000$ diluted SYBR-Green I for $30 \mathrm{~min}$. The bands indicating telomerase activity were quantitatively analyzed using the methods according to the instruction handbook. Telomerase activity was quantified by measuring the signal of telomerase ladder bands and the ratio (TPG units) of telomerase activity to the internal standard and expressed as a percent of the controls.

\section{Results}

Immunohistological chemistry staining. F6 cells were negative for vim (-) and CD117 (-) which were the specific markers for medulloblasts, negative for anti-metastasis protein $\mathrm{nm} 23(-)$, and also negative for cell cycle genes p53 (-) and p16 (-). However, F6 cells were strongly positive for PCNA $(+++)$ (Fig. 1).

Histological type analysis of F6 cells. F6 cells were positive for desmin $(+++)$, the specific marker of muscle; for NSE, $(+++)$, the specific marker for nerve; and for FVIII, $(++)$, the specific marker for endothelial cells in immunohistological chemistry. hMSCs were negative for desmin and NSE, and weakly positive for FVIII (Fig. 2).
Expression of BMI-1 and hTRAP gene in F6 and MSCs. The results of real-time PCR showed that the expression level of the BMI-1 gene in F6 was $\sim 8$ folds higher than that in hMSCs (Fig. 3A). Moreover, the expression level of the hTRAP gene was significantly higher in F6 cells than that in hMSCs ( 992 folds) (Fig. 3B). Western blotting results also showed that the expression of BMI-1 in nuclei of F6 cells was higher than that in hMSCs (Fig. 3C).

Activity of telomerase in F6 cells and MSCs. Telomerase activity by TRAP assay was shown in Fig. 4A. The TPG units of F6 cells and MSCs were 282 and 31, respectively (Fig. 4B). The activity of telomerase in F6 cells was significantly higher than that in MSCs.

Expression of cell cycle-related genes in F6 cells and MSCs. Analysis of RT-PCR revealed that all the fragments of cell cycle-related genes (p16, p21, p53 and pRb) were not detected from the cDNA of F6 cells, however, they were detected from the cDNA of MSCs. The fragments of GAPDH were used as the internal control. (Fig. 5). The same experimental results were obtained by 5 repetitions.

\section{Discussion}

Recently, a hypothesis of cancer stem cells was proposed by researchers that tumors are possibly derived from adult stem 


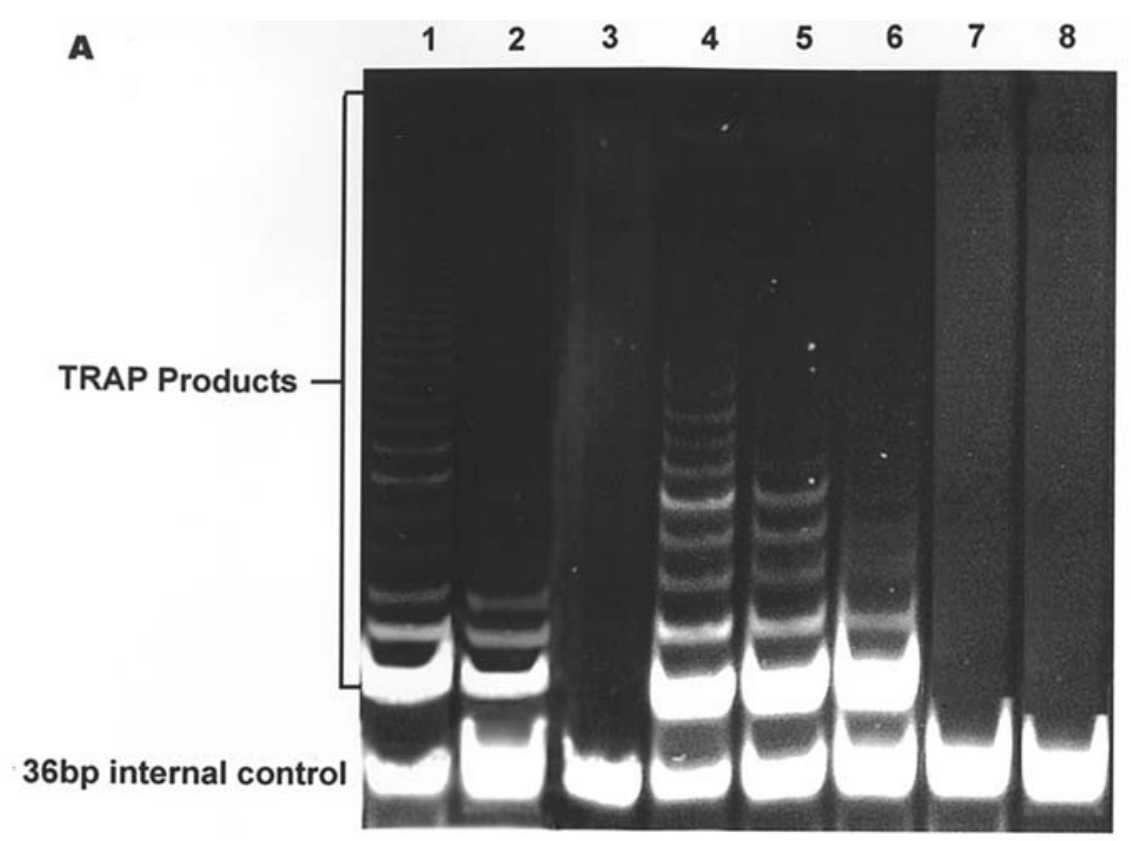

B

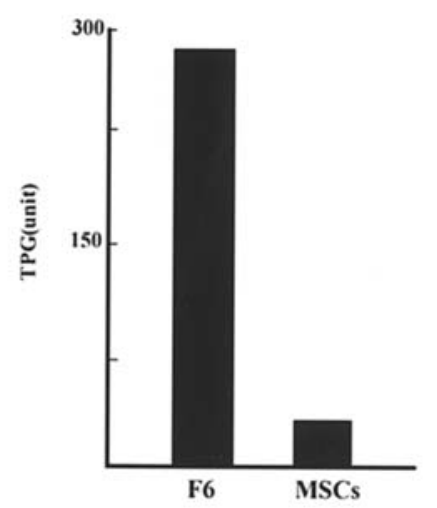

Figure 4. The activity of telomerase was significantly increased in F6 cells compared to human hMSCs. (A) The results of quantitative TRAP assays for the telomerase of F6 cells and hMSCs are shown: Lane 1, F6 cells; lane 2, MSCs; lane 3, blank; lane 4, positive control; lane 5 and 6, TSP control; lane 7, F6 heat inactive; and lane 8, MSCs heat inactive. (B) The activity of telomerase in F6 cells and hMSCs. The TGP unit was calculated according to the manufacturer's protocol.

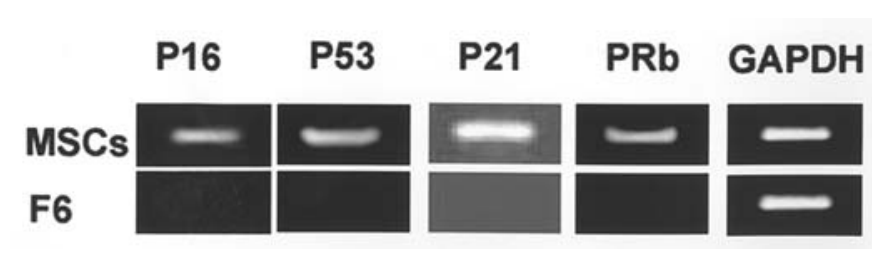

Figure 5. Expression of cell cycle-associated genes in F6 cells. p16, p21, p53 and pRb could not be detected from the cDNA of F6 cells. Endogenous 'housekeeping' gene GAPDH was an internal control.

cells. In all tumor cells there exists a certain type of cells called cancer stem cells which have the same self-renewal ability as stem cells $(4,5,11)$. Cancer stem cells can determine many characteristics of whole tumors, making tumor cells immort and difficult to kill. Some researchers have proved that the mutation of stem cells occurs in vitro due to many factors (11). This new theory revolutionized the classical theory that cancer originates from the mutation of somatic cells. Much experimental evidence contributes to the possibility that the hypothesis of cancer stem cells is well founded. F6 is an example of a type of tumor cell which was directly mutated form embryonic mesenchymal stem cells. Other research groups have also found that stem cells are a potential target of neoplasm.

The transformation of MSCs to F6 occurred under the condition of a high concentration of cytokines. We wondered whether any differentiation occurred in F6 cells, so researching the histological type of F6 cells was very necessary and meaningful. The results revealed that multidirectional differentiation occurred during the mutation. Firstly, F6 cells did not express CD117 and vimentin (specific markers for medulloblasts), which proved that F6 is not a typical medulloblastoma cell as we originally supposed. Secondly, it was interesting that the mutated cells maintained most of the main histological characteristics of hMSCs, which expressed multihistological specific markers, such as desmin, NSE, FVIII, and the expression level was comparatively stronger than MSCs. These results can be used as proof for the relationship 
between hMSCs and cancer, and it has been confirmed that hMSCs can give rise to a variety of differentiated cell types. In turn, many of these tissues can give rise to cancers of mesenchymal origin (12). More clearly, hMSCs can be target cells for neoplastic transformation of these normal mesenchymal and non-mesenchymal tissues.

Moreover, F6 cells were positive for PCNA and negative for nm23, which proved again that F6 cells have a very strong capacity for proliferation and metastasis.

Telomeres, which are nucleoprotein complexes at the chromosome ends, play a critical role in the maintenance of chromosomal integrity $(13,14)$. It is well known that enhanced activity of telomerase is one of the most commonly observed features of cancer cells and is seen in more than $80 \%$ of all human tumors (15). Because the expression and activity of telomerase are quite low in human MSCs (16), which was confirmed again by TRAP assay in our experiment, human MSCs transduced with the telomerase gene developed characteristics similar to tumors $(3,17)$. Meanwhile, TRAP assay also discovered that the activity of telomerase was significantly enhanced in F6 cells, and the increased telomerase activity led to the immortalization and neoplasia of stem cells. hTRAP is a telomerase transcriptional elementinteracting factor, which may take part in the transcriptional activation of hTERT. Overexpression of these genes may lead to overtranscription of hTERT (18). Compared to hMSCs, the expression of F6 was approximately 1000-folds higher than that of MSCs, which further proved that both the transcription and activity of telomerase significantly increased and that telomerase plays a vital role in neoplastic transformation from human MSCs to F6 cells.

F6 cells presented an approximate eight-fold amplification of BMI-1 DNA and the expression level of the protein was higher than that in hMSCs. This gene, which is a member of the polycomb group of transcriptional repressors and was initially identified as an oncogene cooperating with c-myc in a murine model of lymphoma (19), may play an important role in some types of cancer. In previous reports BMI-1 was described to be overexpressed in many kinds of cancer. We also reported that this gene was significantly highly expressed in bone marrow cells extracted from leukemia patients, especially in chronic myeloid leukemia (CML) (20-22). Therefore, the overexpression of BMI-1 in F6 cells may be one of the molecular mechanisms of tumorigenesis.

The downstream targets of BMI-1, P16 ${ }^{\text {INK4a }}$ and $\mathrm{p} 53$ were undetected in DNA expression or in protein level and other important cell cycle-related genes, such as pRb and p21, were also undetected in the transcription of F6 cells, but they were detected in hMSCs. We analyzed the genomic DNA of F6 cells and hMSCs and it was found that these genes were undetected in F6 cells, but were detected in hMSCs (results not shown), This was due mainly to the many deletions and breakage from the chromosome of F6 cells that were found. DNA analysis by FACS indicated that $41.76 \%$ of F6 cells were in $\mathrm{S}$ phase, which significantly surpassed the normal portion (2). This meant that most of the F6 cells passed the G1/S checkpoint into the DNA synthesis phase, because $\mathrm{p} 16 \mathrm{INK} 4 \mathrm{a} / \mathrm{pRb}$ and $\mathrm{p} 19 \mathrm{ARF} / \mathrm{p} 53$ are two pathways in charge of the checkpoint. The deletion of these cell cycle related genes may lead more F6 cells into S phase $(22,23)$.
In conclusion, the F6 cell is a kind of tumor cell with multi-directional differentiation from hMSCs, strong telomerase activity, overexpression of BMI-1 and hTRAP genes, and lost expression of cell cycle-related genes p16, p53, $\mathrm{p} 21$ and $\mathrm{pRb}$. This study was a very interesting model for researching the relationship between cancer and stem cells and providing proof for a molecular mechanism of neoplasia from stem cells.

\section{Acknowledgements}

This work was supported by the National Natural Science Foundation of China, grant no. 30471938, the Natural Science Foundation of Ministry of Public Health of China, grant no. WKJ2005-2-024, Foundation of Zhenjiang Key Institute of Clinical Laboratory Medicine, grant no. SH2006066, SH2006070, and the Scientific Research Foundation of Jiangsu University, grant no. 04JDG028, 04CX07.

\section{References}

1. Passegue E, Jamieson CH, Ailles LE and Weissman IL: Normal and leukemic hematopoiesis: are leukemias a stem cell disorder or a reacquisition of stem cell characteristics? Proc Natl Acad Sci USA 1: 11842-11849, 2003.

2. Xu W, Qian H, Zhu W, Chen Y, Shao Q, Sun X, Hu J, Han C and Zhang X: A novel tumor cell line cloned from mutated human embryonic bone marrow mesenchymal stem cell. Oncol Rep 12: 501-508, 2004

3. Serakinci N, Guldberg P, Burns JS, Abdallah B, Schrodder H, Jensen T and Kassem M: Adult human mesenchymal stem cell as a target for neoplastic transformation. Oncogene 23: 5095-5098, 2004.

4. Al-Hajj M, Wicha MS, Benito-Hernandez A, Morrison SJ and Clarke MF: Prospective identification of tumorigenic breast cancer cells. Proc Natl Acad Sci USA 100: 3983-3988, 2003.

5. Hemmati HD, Nakano I, Lazareff JA, Masterman-Smith M, Geschwind DH, Bronner-Fraser $\mathbf{M}$ and Kornblum HI: Cancerous stem cells can arise from pediatric brain tumors. Proc Natl Acad Sci USA 100: 15178-15183, 2003.

6. Han C, Zhang X, Xu W, Wang W, Qian H and Chen Y: Cloning of the nucleostemin gene and its function in transforming human embryonic bone marrow mesenchymal stem cells into F6 tumor cells. Int J Mol Med 16: 205-213, 2005.

7. Qian H, Xu W, Zhang X, Sun X, Zhu W and Hu J: Basic biological characteristics, isolation and purification of mesenchymal stem cells derived from embryonic bone marrow. Acta Anatomica Sinica 35: 438-442, 2004

8. Xu W, Zhang X, Qian H, Zhu W, Sun X, Hu J, Zhou H and Chen Y: Mesenchymal stem cells from adult human bone marrow differentiated into cardiomyocytes in vitro. Exp Biol Med 229: 623-631, 2004.

9. Sun X, Xu W, Yao K, Hu J, Qian H and Zhang X: Preliminary research on induction of fetal bone marrow mesenchymal stem cells differentiation into neural cells in vitro. Chinese J Biol Eng 23: 40-43, 2004.

10. Zhu W, Xu W, Sun X and Lian F: An experimental study on osteogenic differentiation of bone marrow mesenchymal stem cells in vitro. J Biol Eng Res 22: 41-43, 2003.

11. Singh SK, Clarke ID, Terasaki M, Bonn VE, Hawkins C, Squire J and Dirks PB: Identification of a cancer stem cell in human brain tumors. Cancer Res 63: 5821-5828, 2003.

12. Keith WN: From stem cells to cancer: balancing immortality and neoplasia. Oncogene 23: 5092-5094, 2004.

13. Maser RS and DePinho RA: Connecting chromosomes, crisis and cancer. Science 297: 565-569, 2002.

14. de Lange T: Protection of mammalian telomeres. Oncogene 21 532-540, 2002.

15. Blasco MA: Telomeres and human disease: ageing, cancer and beyond. Nat Rev Genet 6: 611-622, 2005.

16. Zimmermamn S, Voss M, Kaiser S, Kapp U, Waller CF and Martens UM: Lack of telomerase activity in human mesenchymal stem cells. Leukemia 17: 1146-1149, 2003. 
17. Minguell JJ, Fierro FA, Epunan MJ, Erices AA and Sierralta WD Nonstimulated human uncommitted mesenchymal stem cells express cell markers of mesenchymal and neural lineages. Stem Cells Dev 14: 408-414, 2005

18. Tang Z, Zhao Y, Mei F, Yang S, Li X, Lv J, Hou L and Zhang B: Molecular cloning and characterization of a human gene involved in transcriptional regulation of hTERT. Biochem Biophys Res Commun 324: 1324-1332, 2004.

19. Haupt Y, Bath ML, Harris AW and Adams JM: Bmi-1 transgene induces lymphomas and collaborates with myc in tumorigenesis. Oncogene 8: 3161-3164, 1993.

20. Park IK, Qian D, Kiel M, Becker MW, Pihalja M, Weissman IL, Morrison SJ and Clarke MF: Bmi-1 is required for maintenance of adult self-renewing haematopoietic stem cells. Nature 423: 302-305, 2003.
21. Bea S, Tort F, Pinyol M, Puig X, Hernandez L, Hernandez S, Fernandez PL, van Lohuizen M, Colomer D and Campo E: BMI-1 Gene amplification and overexpression in hematological malignancies occur mainly in mantle cell lymphomas. Cancer Res 61: 2409-2412, 2001.

22. Jacobs JJ, Kieboom K, Marino S, DePinho RA and van Lohuizen M: The oncogene and Polycomb-group gene bmi-1 regulates cell proliferation and senescence through the ink4a locus. Nature 397: 164-168, 1999.

23. Lessard J and Sauvageau G: Bmi-1 determines the proliferative capacity of normal and leukaemic stem cells. Nature 423: 255-260, 2003. 